\title{
KAJIAN TIMBULAN SAMPAH MAKANAN WARUNG MAKAN
}

\author{
Desi Wulansari $^{1 *}$, Meti Ekayani ${ }^{2)}$, Lina Karlinasari ${ }^{3)}$ \\ ${ }^{1)}$ Pascasarjana Ilmu Pengelolaan Sumberdaya Alam dan Lingkungan IPB \\ ${ }^{2}$ Dept. Ekonomi Sumberdaya Lingkungan IPB \\ ${ }^{3)}$ Dept. Hasil Hutan IPB \\ *Email: desi_psl17@apps.ipb.ac.id
}

\section{ABSTRACT \\ STUDY OF WARUNG MAKAN'S FOOD WASTE}

The existence of IPB with a high number of students and residents influences the development of the area. Various businesses emerged to satisfy the needs of students, one of them is warung makan. Warung makan isthe one of food waste sources that comes from leftlovers. Food waste can have an impact on the environment, social and economic. This study aims to determine the amount of food waste from warung makan and to determine the efforts to reduce the food waste. This research was conducted in around the campus of IPB Darmaga. The methodology used SNI 19-3964-1994. The results show that the average of food waste warung makan was $29,413 \mathrm{~kg} /$ day. The food waste composition consists of rice, vegetables and side dishes with the largest component was rice about $70 \%$ of totalfood waste. Efforts can be made to reduce the food waste from the side of warung makanwas apply the method of serving rice on a buffet basis,apply a choice of rice portions, and campaign about food waste.

Keywords : food waste, food waste campaign, leftlovers, warung makan

\section{PENDAHULUAN}

Sampah makanan (food waste) merupakan makanan yang dapat dikonsumsi manusia tetapi tidak dikonsumi dan dibuang dengan alasan-alasan tertentu (FAO, 2011). Sementara Bond et al. (2013)memberikan definisi sampah makanan sebagai makanan yang dapat dimakan dan untuk manusia tetapi dibuang, hilang, rusak atau dikonsumsi hewan dan termasuk bagian yang tidak dimakan. Sampah makanan mulai menjadi isu di berbagai negara karena bebagai dampak yang ditimbulkan. Abiad et al.,(2018) menyatakan bahwa sampah makanan berdampak padaketahanan pangan, lingkungan dan ekonomi. Sebanyak 1,3 miliar ton bahan makanan yang layak untuk dikonsumsi (sepertiga dari produksi pangan dunia) terbuang di sepanjang rantai pasokan makanan dari tahap produksi hingga konsumsi (Gustavsson et. Al., 2011). Jumlah makanan yang terbuang tersebut dapat memenuhi kebutuhan pangan seperdelapan populasi global yang mengalami kekurangan pangan dan gizi. Selain itu, jumlah tersebut juga dapat mengurangi tantangan dalam memenuhi kebutuhan pangan global yang meningkat $50 \%$ hingga $70 \%$ pada tahun 2050 (FAO, 2009). Sampah makanan yang dibuang begitu saja ke tempat pembuangan sampah atau TPA, tanpa adanya perlakuan yang tepat dapat menjadi sumber metana yang menyebabkan pemanasan global. Menurut IPCC (2007) sampah makanan yang ditimbun di tempat pembuangan akan dikonversi menjadi metana yang merupakan gas rumah kaca dan berpotensi pada pemanasan global 21 kali lebih besar dari $\mathrm{CO}_{2}$.Selain itu, Levis dan Barlaz (2011) menambahkan bahwa sampah makanan cenderung terdegradasi lebih cepat dan metana yang dihasilkan lebih tinggi dibandingkan bahan organik lainnya yang ditimbun di tempat pembuangan sampah. Membuang sampah makanan sama dengan membuang sumberdaya. Secara ekonomi, sampah makanan menyebabkan adanya kerugian ekonomi yang digunakan untuk menghasilkan makanan, seperti pengadaan bahan baku makanan, air, energi dan sebagainya (FAO, 2014). 
Sama halnya dengan negara-negara lain. Indonesia juga tidak terlepas dari isu sampah makanan. Hasil studi yang dilakukan oleh The Economist Intelligent Unit (EIU) dalam laporannya "Food Sustainability Index" pada tahun 2017 menyatakan bahwa Indonesia merupakan negara yang memproduksi sampah makanan terbesar kedua setelah Arab Saudi (EIU, 2017).Hasil tersebut didukung oleh data dari Sistem Informasi Pengelolaan Sampah Nasional (SIPSN) Kementerian LHK, komposisi sampah terbesar di Indonesia pada tahun 2017-2018 adalah sampah makanan, yaitu mencapai 93\% (SIPSN, 2018). Lebih rinci SIPSN menambahkan bahwa pada periode 2017-2018 komposisi sampah di Kabupaten Bogor didominasi oleh sampah makanan hingga mencapai $70 \%$.

Keberadaan Institut Pertanian Bogor (IPB) sebagai salah satu dari lima Perguruan Tinggi Negeri (PTN) terbaik di Indonesia menyebabkan peningkatan jumlah penduduk di Kabupaten Bogor, khusunya penduduk pendatang. Berdasarkan data dari Pangkalan Data Kemenristek Dikti, jumlah mahasiswa IPB tahun 2017/2018 mencapai 27.260 mahasiswa. Jumlah mahasiswa tersebut belum termasuk jumlah penduduk yang berada di sekitar kampus. Hal itu menyebabkan potensi timbulan sampah di Kabupaten Bogor juga tinggi. Selain itu, adanya kampus juga memicu timbulnya berbagai jenis usaha masyarakat untuk menunjang kebutuhan mahasiswa dan masyarakat disekitar kampus. Salah satu usahatersebut adalah usaha makanan,seperti warung makan.

Warung makan merupakan salah satu sumber penghasil sampah, baik sampah makanan (food waste) dan non food waste. Banyaknya usaha makanan di sekitar Kampus IPB, menimbulkan dugaan bahwa jumlah sampah makanan yang dihasilkan juga tinggi. Usaha makanan setiap harinya menyediakan makanan dan memicu timbulnya sampah makanan. Silvennoinen et al (2015) menyatakan bahwa pada sektor jasa penyedia makanan, timbulan sampah dapat berasal dari tahap konsumsi yang merupakan sisa makanan dari konsumen yang tidak terkonsumsi. Betz et al. (2015) menyatakan bahwa jasa penyedia makanan memiliki peran penting dalam manajemen sampah makanan karena sebagian besar makanan dibuang pada tahap persiapan atau makanan tersebut tidak dapat digunakan kembali (tahap penyajian). Pada penelitian ini kajian sampah makanan dilakukan pada tahap konsumsi agar dapat diketahui perilaku konsumen dalam menyisakan makanan. selain itu informasi timbulan sampah,khususnya sampah makanan dapat menjadi informasi bagi pengelola sampah untuk mengetahui jumlah dan komposisi sampah makanan yang dihasilkan dari warung makan sehingga dapat menentukan upaya untuk mengurangi timbulan sampah makanan tersebut.

\section{METODOLOGI}

\subsection{Lokasi dan Sampel Penelitian}

Penelitian dilaksanakan di Desa Babakan, Kecamatan Dramaga, Kabupaten Bogor,khususnya Jalan Babakan Raya hingga Babakan Tengah sepanjang $800 \mathrm{~m}$. Penelitian dilakukan pada Bulan Januari sampai dengan Maret 2019. Penentuan sampel penelitian dilakukan dengan teknik purposive sampling dengan membagi sampel warung makan menjadi 4 kategori, yaitu Padang, Sunda, Tegal dan A La Carte. Jumlah sampel warung makan masing-masing kategori ditunjukkan pada Tabel 1.

Tabel 1 Sampel Berdasarkan 4 Kategori Warung Makan

\begin{tabular}{clc}
\hline No & Jenis warung makan & Sampel (n) \\
\hline 1 & Padang & 1 \\
2 & Sunda & 5 \\
3 & Tegal & 4 \\
4 & A La Carte & 6 \\
\hline \multicolumn{2}{c}{ Total } \\
\hline
\end{tabular}


Warung Padang merupakan Warung yang khusus menyediakan masakan khas Padang. Setiap sajian masakan Padang terdiri dari nasi, sayur nangka muda, daun singkong, dan aneka lauk hewani, seperti rendang, ikan, daging cincang dan sebagainya serta lauk nabati, seperti tempe, tahu goreng dan perkedel. Warung makan Sunda merupakan warung makan yang menyediakan sajian masakan khas Sunda yang terdiri dari nasi, aneka lauk hewani, lalap, sambal dan tahu tempe sebagai lauk pendamping. Warung Tegal seperti yang diketahui bersama merupakan jenis warung yang menyediakan beraneka pilihan makanan tradisional, atau makanan rumahan yang siap dikonsumsi. Sementara jenis $A$ La Carte merupakan jenis warung yang menerapkan sistem menu, sehingga makanan dimasak setelah konsumen menentukan menu yang diinginkan.

Hal-hal yang menjadi ruang lingkup dari penelitian ini adalah:

1. Penelitian dilakukan pada usaha warung makan yang memiliki bangunan permanen yang dapat mengolah makanan ditempat (memiliki dapur)

2. Makanan yang dibeli secara take away tidak termasuk dalam perhitungan pada penelitian ini

3. Bagian makanan yang bukan untuk tujuan konsumsi, seperti kulit buah atau tulang ikan dan ayam tidak termasuk dalam perhitungan kerugian ekonomi.

4. Cairan seperti kuah sayur dan sup tidak termasuk dalam perhitungan pada penelitian ini.

\subsection{Prosedur Pengambilan dan Analisis Data}

Pengambilan data sampah makanan dilakukanpada saat hari belajar efektif sehingga jumlah mahasiswa di dalam Kampus diasumsikandalam kondisi full capacity. Pengambilan data dilakukan selama 8 hari sesuai dengan SNI 19-3964-1994 (BSN, 1994). Prosedur pengambila data sampah makanan adalah:

1. Masing-masing warung makan diberikan satu kantong plastik untuk menampung sampah makanan sisa konsumsi mulai dari warung makan tersebut buka hingga menjelang tutup.
2. Sampah makanan yang telah terkumpul dari masing-masing warung makankemudian dilakukan penimbangan menggunakan timbangan digital dengan ketelitian 1 gram. Timbulan sampah dihitung berdasarkan satuan berat per warung makan ( $\mathrm{Kg} /$ warung makan).

3. Sampah makanan dipilah berdasarkan komponennya, yaitu nasi, sayur dan lauk untuk menghitung komposisi sampah makanan per warung makan.

Data sampah makanan yang telah dikumpulkan kemudian dilakukan perhitungan timbulan sampah warung makan dengan persamaan-persamaan matematis yang mengacu pada SNI 19-3964-1994 tentang Metode Pengambilan dan Pengukuran Contoh Timbulan dan Komposisi Sampah Perkotaan. Timbulan sampah makanan per tahun ditentukan dengan mengalikan timbulan sampah per hari dengan jumlah hari dalam satu tahun pada saat hari kuliah aktif (217 hari) seperti pada persamaan berikut.

$$
T T s=T s x d
$$

Keterangan :

$\mathrm{TT}_{\mathrm{s}} \quad$ : Timbulan sampah $(\mathrm{Kg} / \mathrm{th})$

$\mathrm{T}_{\mathrm{s}} \quad$ : Total timbulan sampah warung makan $(\mathrm{Kg} / \mathrm{hari})$

d : Jumlah hari pada setiap kondisi dalam 1 tahun (hari/th)

Selain timbulan sampah juga dihitung komposisi sampah makanan. Pengukuran komposisi sampah merupakan pemilahan berdasarkan komponen dari sampah makanan, misalnya nasi, sayur, lauk dan komponen lainnya. Menurut SNI 19-39641994, komposisi sampah diukur dengan cara menimbang masing-masing komponen sampah makanan yang telah dipilah, setelah diperoleh berat komponen sampah kemudian dibagi dengan berat total sampah makanan keseluruhan. Hasil perhitungan timbulan dan komposisi sampah makanan kemudian dianalisis decara deskriptif. Rumus menghitung komposisi sampah makanan adalah sebagai berikut. 


$$
\% \text { Komposisi }=\frac{B i}{T B i} \times 100 \%
$$

Keterangan :

$\mathrm{B}_{\mathrm{i}} \quad$ : Berat komponen sampah warung makan i $(\mathrm{Kg})$

$\mathrm{TB}_{\mathrm{i}} \quad$ : Total berat sampah keseluruhan warung makan i $(\mathrm{Kg})$

Sampel penelitian juga melibatkan pengunjung warung makan sebagai konsumen. Pengambilan sampel responden konsumen dilakukan dengan teknik incidental sampling. Menurut Sugiyono (2009) teknik incidental sampling dilakukan berdasarkan kebetulan, yaitu siapa saja yang secara kebetulan ditemuidapat menjadi sampel penelitian. Oleh karena itu, pada penelitian ini siapa saja konsumen yang ditemui di masingmasing jenis sampel warung makan dapat dijadikan sebagai responden konsumen. Sampel responden konsumen dalam penelitian ini diperoleh sebanyak 75 responden.

\section{HASIL DAN PEMBAHASAN}

\subsection{Timbulan Sampah Makanan Warung Makan}

Timbulan sampah makanan warung makan dihitung berdasarkan sisa makanan yang masih layak dimakan tetapi tidak habis dikonsumsi oleh pengunjung atau konsumen. Berdasarkan analisis timbulan sampah pada warung makan diperoleh timbulan sampah per tahun seperti ditunjukkan pada Tabel 2.

Tabel 2. Timbulan Sampah Makanan Warung Makan per Tahun

\begin{tabular}{lcc}
\hline \multirow{2}{*}{ Warung Makan } & \multicolumn{2}{c}{ Timbulan sampah } \\
\cline { 2 - 3 } & $(\mathrm{Kg} / \mathrm{hari})$ & $(\mathrm{Kg} / \mathrm{th})$ \\
\hline Padang & 5,536 & 1.201 \\
Sunda & 5,036 & 1.093 \\
Tegal & 8,502 & 1.845 \\
A La Carte & 10,338 & 2.243 \\
\hline Total & 29,413 & 6.383 \\
\hline $\mathrm{d}^{*}:$ jumlah hari efektif dalam 1 tahun $=217$ hari & &
\end{tabular}

Hasil analisis timbulan sampah menunjukkan bahwa jenis warung A La Carte menghasilkan timbulan sampah terbesar $(10,338 \mathrm{Kg} / \mathrm{hari})$ dan timbulan sampah terkecil pada warung Sunda $(5,036 \mathrm{Kg} / \mathrm{hari})$. Dalam sehari warung makan dari seluruh jenis warung menghasilkan sampah makanan sebesar 29,413 Kg atau sekitar 6 ton/tahun.Saat ini, warung makan jenis $A L a$ Carte menjadi daya tarik tersendiri bagi konsumen yang sebagian besar mahasiswa. Pilhan menu yang ditawarkan sangat beragam dan kekinian. Pengunjung dapat memilih makanan sesuai menu yang ditawarkan dan koki akan memasak setelah pengunjung memilih menu, sehingga makanan akan lebih segar. Namun, umumnya warung $A$ La Carte menyajikan makanan dengan porsi yang cukup besar, sehingga hal itu dapat berpotensi menimbulkan sampah makanan.
Warung Tegal masih menjadi pilihan pengunjung ditengah banyaknya jenis warung makan baru yang kekinian. Hal itu ditunjukkan dengan jumlah sampah makanan warung Tegal juga cukup banyak $(8,502 \mathrm{~kg} /$ hari $)$. Tingginya minat konsumen terhadap warung Tegal disebabkan warung tersebut menyediakan makanan rumahan dan tradisional. Warung Tegal setiap hari menyediakan lebih dari 20 jenis makanan siap konsumsi. Banyaknya pilihan makanan,porsi yang cukup banyak dan harga yang relatif murah juga menjadi alasan jenis warung ini banyak dikunjungi. Banyaknya pengunjung di warung makan tersebut belum dapat dikatakan bahwa timbulan sampah yang dihasilkan juga semakin besar karena hal itu tergantung pada banyak sedikitnya sisa makanan yang dihasilkan oleh konsumen.

Umumnya jenis makanan yang disajikan dari setiap warung Sunda hampir 
sama. Aneka pilihan lauk hewani, seperti ayam dan ikan yang diolah dengan digoreng atau dipanggang, dipadukan denganlalap, sambal dan lauk pendamping seperti tahu dan tempemenjadi bagian tak-terpisahkan dari sajian makanan Sunda. Harga pangan hewani yang relatif lebih mahal dibandingkan harga sayuran mempengaruhi persepsi masyarakat dalam menilai suatu makanan. Konsumen akan merasa rugi apabila menyisakan makanan yang memiliki harga lebih tinggi dibandingkan yang lain. Selain itu makanan yang dibeli dengan harga yang relatif mahal akan terasa lebih enak, sehingga cennderung akan dikonsumsi hingga habis. Berdasarkan informasi yang dikutip dari Detik Food edisi 3 Mei 2014 terdapat hasil studi baru dari Cornell University di Restoran Italia yang menemukan bahwa konsumen yang membeli makanan dengan harga yang lebih mahal, lebih menikmati makanannya $11 \%$ lebih tinggi daripada makanan yang dibeli dengan harga yang lebih murah. Oleh karena itu pada jenis warung Sunda cenderung menghasilkan lebih sedikit sampah makanan.
Berdasarkan jumlah sampah makanan tersebut belum dapat diketahui komponen sampah makanan terbesar yang menjadi sampah makanan dari sisa konsumsi konsumen. Oleh karena itu perlu diketahui juga komposisi sampah makanan yang dihasilkan di warung makan.

A. Komposisi sampah makanan warung makan

Menurut Tchobanoglous et al. (1993) dalam Raharjo dan Geovani (2015) komposisi sampah menyatakan komponenkomponen yang terdapat pada sampah, biasanya dinyatakan dalam $\%$ berat dan digunakan untuk menentukan peralatan yang diperlukan, sistem manajemen dan perencanaan dalam pengelolaan sampah.Komposisi sampah makanan warung makan terdiri dari 3 komponen, yaitu nasi,sayur dan lauk. Besarnya komposisi sampah makanan masing-masing jenis warung makan ditunjukkan pada Gambar 1 .

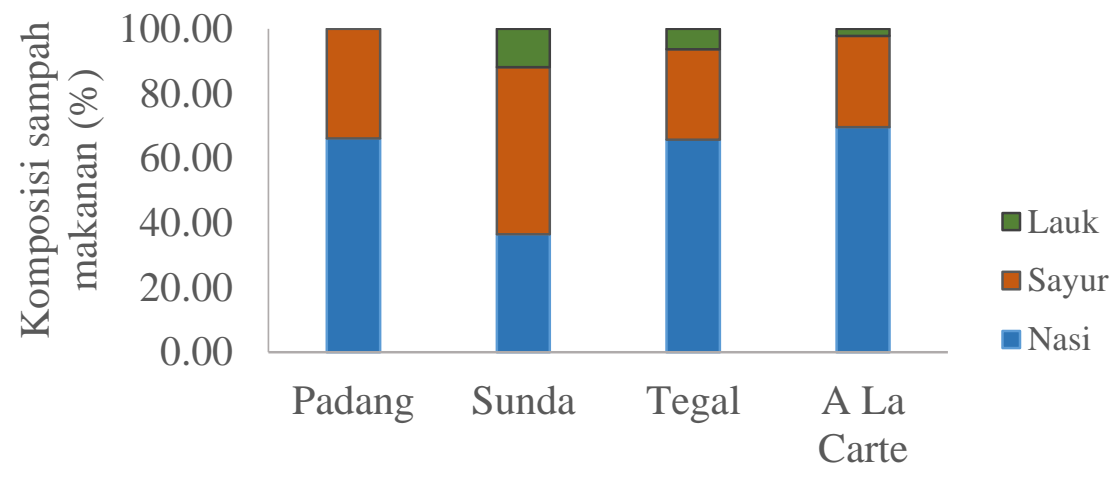

Kategori warung makan

Gambar 1.

Komposisi Sampah Makanan Warung Makan

Gambar1 menunjukkan bahwa komponen sampah makanan terbesar adalah nasi dan paling kecil adalah komponen lauk. Pada Warung Padang, Tegal dan A La Carte komponen terbesar adalah nasi hingga mencapai sekitar $60 \%$ dari berat sampah total yang dihasilkan masing-masing warung tersebut. Sementara pada warung Sunda komponen terbesar adalah sayur. Warung Tegal dan A La Carte umumnya menyajikan nasi dengan porsi yang besar. Porsi tersebut mungkin saja melebihi porsi nasi yang dibutuhkan konsumen, sehingga pada akhirnya terbuang menjadi sampah makanan. Banyaknya nasi yang terbuang tersebut menunjukkan bahwa telah terjadi pergeseran konsumsi pangan karbohidrat. Konsumsi nasi yang selama ini menjadi bahan pangan utama bagi masyarakat menurun dan digantikan dengan meningkatnya konsumsi pangan berprotein. Sementara pada warung Padang, meskipun nasi disajikan dengan takaran 
tertentu konsumen dapat meminta tambahan 1 porsi nasi yang telah disiramdengankuah khas masakan Padang. Hal ini menyebabkan sampah makanan apabila konsumen tidak mengkonsumsi nasi seluruhnya. Timbulan sampah makanan menunjukkan adanya inefisiensi konsumsi. Pengadaan makanan melibatkan sumberdaya yang bertujuan untuk memenuhi kebutuhan pangan masyarakat. Namun ketika makanan tersebut tidak dikonsumsi secara keseluruhan dan kemudian terbuang menjadi sampah makanan, dapat dikatakan bahwa sumberdaya yang digunakan tersebut juga ikut terbuang.

Salah satu hal yang menarik mengenai konsumsi nasi adalah pada warung Tegal. Pada Warung Tegal umumnya konsumen ditawarkan pilihan porsi nasi yaitu porsi penuh (satu) atau porsi setengah dengan perbedaan harga RP. 1000. Hasil wawancara pada 75 responden diperoleh sebagian besar konsumen memilih porsi penuh meskipun kebutuhan nasi yang sebenarnya adalah porsi setengah (Gambar 2). Koivupuro et al (2012) menyatakan bahwa salah satu faktor yang memungkinkan terjadinya sampah makanan adalah terkait harga dan ukuran paket atau porsi.Responden konsumen yang diketahui hampir keseluruhan (90\%) merupakan mahasiswa umumnya lebih memilih porsi yang lebih besar dengan harga yang lebih murah dengan alasan agar dapat lebih hemat. Hal ini didukung oleh Aschemann-Witzel et al (2016) yang menyatakan bahwa penawaran yang terkait dengan ukuran paket dan harga akan menggiring konsumen untuk membeli paket (porsi) yang lebih besar daripada yang kecil untuk alasan ekonomi.

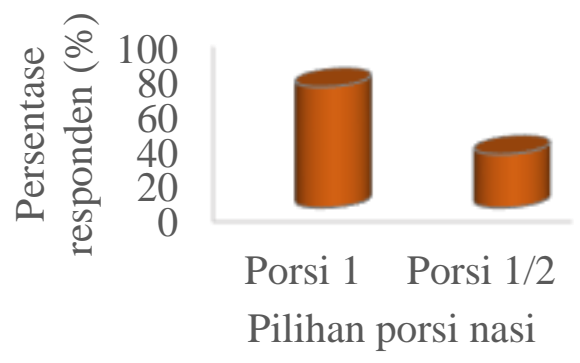

Gambar 2.

Pilihan Porsi Apabila Terdapat Perbedaan Harga per Porsi
Komponen sayur yang memiliki persentase terbesar pada warung Sunda merupakan sayur mentah, yaitu berupa lalapan. Lalapan terdiri dari beberapa sayuran segar yang menjadi bagian dari sajian masakan Sunda. Kesegaran bahan, lalapan yang dikonsumsi langsung dengan sambal merupakan ke-khasandari masakan Sunda (Fajri, 2018). Namun, bagi pengunjung yang tidak menyukai lalapan atau sengaja menghindari lalapan, sayuran tersebut pada akhirnya terbuang dan menjadi sampah makanan.Sayuran yang digunakan untuk lalap di Warung Sunda berbeda-beda, biasanya terdiri dari beberapa kombinasi dari sayuran berikut, yaitu selada, mentimun, kol dan daun kemangi. Sementara komponen lauk terdiri dari lauk hewani dan lauk nabati.

\subsection{Upaya Mengurangi Timbulan Sampah Nasi Warung Makan}

Sampah makanan dari tahap konsumsi yang berasal dari konsumen berkaitan dengan cara penyajian makanan oleh pemilik warung dan perilaku konsumsi konsumen. Mengurangi timbulan sampah makanan perlu kesadaran dari konsumen itu sendiri untuk dapat memilih makanan secara bijak dan bertanggung jawab. Pada tahun 2015 United States melalui Environmental Protecting Agency (EPA) mencetuskan suatu konsep pengelolaan sampah makanan yang dikenal dengan konsep Food Recovery Hierarchy. Konsep ini bertujuan untuk mengurangi sampah makanan dan melindungi lingkungan akibat dampak negatif dari sampah makanan. Konsep Food Recovery Hierarchy berbentuk piramida terbalik yang menunjukkan urutan prioritas tindakan yang dilakukan terhadap sampah makanan.

Tindakan yang menjadi prioritas utama dalam konsep tersebut adalah pengurangan sampah makanan dari sumbernya. Pada penelitian ini sumber sampah makanan adalah warung makan yang didalamnya melibatkan produsen atau pemilik warung dan pengunjung warung makan sebagai konsumen. Hal ini menunjukkaan bahwa mengurangi sampah makanan sisa konsumsi dari warung makan bukan hanya tanggung jawab konsumen yang secara langsung 
mengkonsumsi makanan, namun warung makan juga memilikiperan untuk membantu mengurangi timbulan sampah dalam hal penyajian makanan kepada konsumen. Kebijakan atau aturan dapat diterapkan di warung makan sebagai upaya untuk mengurangi sampah makanan sisa konsumsi konsumen. Beberapa hal yang dapat dilakukan sebagai upaya mengurangi timbulan sampah makanan warung makan adalah :

1. Menerapkan cara penyajian nasi secara prasmanan

Komposisi terbesar sampah makanan yang dihasilkan warung makan menunjukkan bahwa nasi menempati urutan pertama persentase yang paling besar. Menurunnya konsumsi nasi konsumen juga perlu diimbangi dengan cara penyajian nasi yang diterapkan di warung makan sebagai upaya mengurangi sampah makanan, khususnya nasi. Hasil penelitian Anriany dan Martianto (2013) juga menyatakan bahwa cara penyajian mempengaruhi jumlah sisa makanan yang dihasilkan.

Berdasarkan pengamatan karakteristik masing-masing warung makan, terdapat 3 macam cara penyajian nasi di lokasi penelitian. Cara penyajian tersebut adalah prasmanan, penyajian nasi tanpa takaran dan penyajian nasi dengan takaran. Menurut Kamus Besar Bahasa Indonesia (KBBI), prasmanan adalah cara menjamu makanan dengan mempersilahkan tamu mengambil dan memilih sendiri hidangan yang telah disiapkan. Pada penelitian ini, istilah prasmanan hanya diberlakukan pada nasi, tidak untuk hidangan yang lain. Penyajian nasi tanpa takaran adalah cara penyajian yang dilayani oleh penjual tanpa ada ukuran tertentu. Banyaknya nasi yang disajikan kepada konsumen tergantung pada penjual yang memiliki kewenangan untuk menyajikan. Sementara pada penyajian nasi dengan takaran, nasi disajikan dengan takaran tertentu, seperti mangkuk kecil atau takaran khusus untuk nasi.

Jenis atau kategori warung makan yang berbeda tidak selalu memiliki cara penyajian nasi yang berbeda pula. Terdapat jenis warung makan yang berbeda tetapi memiliki cara penyajian nasi yang sama.Oleh karena itu, padapenelitian inisampel warung makan dikelompokkan berdasarkan cara penyajian nasi untuk mengetahui perbedaan jumlah sisa nasi yang dihasilkan sebagai sampah makanan.Hasil menunjukkan bahwa pada warung makan yang menerapkan penyajian nasi secara prasmanan rata-rata timbulan sampah makanan per hari lebih kecil dibanding cara penyajian yang lainnya $(0,42$ $\mathrm{kg} /$ hari ). Secara rinci, timbulan sampah makanan per hari dari masing-masing cara penyajian nasi ditunjukkan pada Gambar 3.

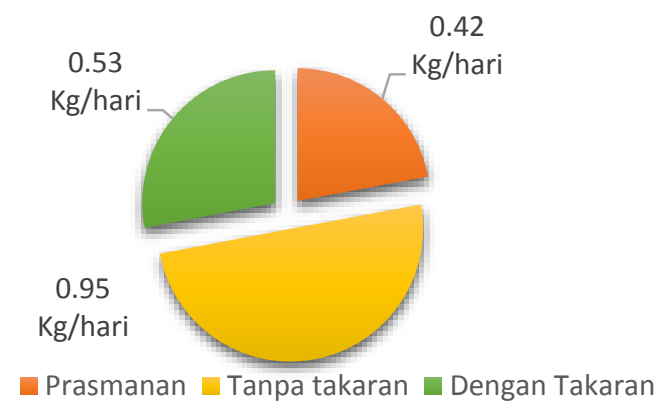

Gambar 3.

Rata-rata timbulan sampah berdasarkan cara penyajian makanan

Gambar 3 menunjukkanbahwa penyajian nasi secara prasmanan dan penyaian nasi dengan takaranmenghasilkan rata-rata nasi per hari yang tidak berbeda jauh. Pada penyajian nasi dengan takaran, umumnya jumlah nasi yang disajikan lebih sedikit dibandingkan dengan penyajian nasi tanpa takaran. Namun, takaran yang digunakan masing-masing warung makan memiliki ukuran yang berbeda-beda sehingga memungkinkan jumlah nasi yang disajikan tersebut melebihi kebutuhan konsumen dan pada akhirnya terbuang menjadi sampah makanan. Sementara pada penyajian nasi secara prasmanan, konsumen diberi kebebasan untuk mengambil nasi sesuai keinginan dan kebutuhan. Selain itu konsumen juga diperbolehkan mengambil nasi berulang kali dengan tidak dibebani tambahan biaya untuk nasi. Cara penyajian seperti ini menyebabkan konsumen dapat mengambil nasi dengan porsi kecil kemudian mengambil kembali apabila dirasa kurang. 
Oleh karena itu, potensi nasi terbuang menjadi sampah makanan sangat rendah.

Berbeda dengan kedua cara sebelumnya, penyajian nasi tanpa takaran tidak memperkirakan kebutuhan nasi konsumen yang berbeda-beda. Konsumen disajikan nasi sesuai dengan takaran yang berlaku di warung makan tersebut dan umumnya jumlah nasi lebih banyak dibandingkan dengan nasi yang disajikan dengan takaran. Konsumen yang kebutuhan nasinya lebih kecil dari jumlah nasi yang disajikan akan berpotensi untuk menyisakan nasi dan kemudian terbuang menjadi sampah makanan. Berdasarkan hasil dan analisis tersebut, maka warung makan dapat mencoba untuk menerapkan penyajian nasi secara prasmanan sebagai upaya mengurangi sampah makanan dari sumbernya khususnya yang berasal dari sisa konsumsi konsumen.

\section{Menerapkan pilihan porsi nasi}

Warung makan di sekitar kampus, khususnya yang menyajikan nasi tanpa takaranbiasanya menawarkan pilihan porsi nasi bagi konsumen. Saat mengunjungi warung makan tersebut, konsumen diberi pilihan porsi nasi, yaitu porsi penuh (porsi 1) atau porsi setengah. Penawaran porsi nasi bertujuan agar konsumen dapat meperhitungkan kebutuhan nasi masingmasing. Kedua porsi tersebut biasanya memiliki perbedaan harga Rp. 1000. Cara yang selama ini diterapkan adalah porsi setengah memiliki jumlah atau kuantitas setengah lebih kecil dari porsi nasi. Namun harga porsi setengah tidak setengah lebih murah dari harga 1 porsi nasi. Hal ini menyebabkan konsumen lebih memilih porsi penuh dibandingkan porsi setengah.

Konsep pilihan porsi nasi dapat digunakan sebagai upaya untuk mengurangi sampah makanan warung makan, namun cara penerapannya perlu dibuat berbeda dengan cara yang selama ini digunakan. Apabila pilihan porsi nasi diterapkan dengan harga nasi pada porsi setengah sama dengan setengah lebih murah dari harga porsi penuh, konsumen akan lebih berhati-hati dalam menentukan porsi makanan yang akan dipilih.
Menurut Brian Wansink, seorang profesor Dyson School of Applied Economics and Management di Cornell University, harga makanan dapat mempengaruhi bagaimana konsumen menilai dan menghargai makanan (Detik Food, edisi 3 Mei 2014). Berdasarkan cara ini, konsumen yang membutuhkan nasi dalam porsi setengah akan membeli nasi dengan porsi setengah, begitu pula dengan konsumen yang memiliki kebutuhan nasi dalam porsi penuh. Apabila konsumen mengkonsumsi nasi sesuai dengan kebutuhan masing-masing, potensi menyisakan makanan dapat lebih kecil dan timbulan sampah makanan dari sisa konsumsi konsumen warung makan juga akan berkurang. Oleh karena itu, penyajian nasi dengan cara ini diharapkan dapat mempengaruhi konsumen agar dapatlebih menghargai makanan dan mengubah perilaku membuag makanan.

\section{Melakukan kampanye tentang sampah makanan}

Cara lain yang dapat dilakukan oleh warung makan untuk mengurangi sampah makanan selain menerapkan cara penyajian nasi secara prasmanan juga dapat melalui kampanye. Kampanye tersebut dapat dilakukan dengan memasang slogan-slogan yang berkaitan dengan sampah makanan. Slogan merupakan kalimat singkat,menarik dan bersifat persuasif. Slogan-slogan sampah makanan dapat menjadi himbauan secara tidak langsung kepada konsumen. Slogan tersebut dibuat secara menarik dan dipasang di dinding-dinding warung makan agar dapat menarik minat konsumen untuk membacanya. Selain dapat menghiasi dinding warung makan, secara tidak langsung slogan tersebut juga dapat memberikan informasi bagi konsumen. Salah satu contoh slogan tentang sampah makanan adalah "Makananmu Tanggungjawabmu". Adanya sloganslogantentang sampah makanan tersebut diharapkan dapat menjadi perhatian bagi konsumen untuk lebih bijaksana dalam mengkonsumsi makanan.

Selain slogan kampanye untuk mengurangi sampah makanan juga dapat melalui poster. Poster berisi gambar-gambar tentang dampak akibat perilaku menyisakan 
makanan yang kemudian menghasilkan sampah makanan. Poster dapat menjadi media pemberi informasi bagi konsumen yang belum mengenal dan mendengar isu-isu mengenai sampah makanan. Sama seperti slogan, poster juga perlu dibuat sedemikian rupa agar dapat menarik perhatian konsumen untuk membacanya.

\section{SIMPULAN DAN SARAN}

\subsection{Simpulan}

1. Timbulan sampah makanan warung makan sebesar $29.413 \mathrm{~kg} / \mathrm{hari}$ atau $6,383 \mathrm{ton} / \mathrm{th}$. Komposisi sampah makanan terbesar adalah nasi sekitar $70 \%$ dari total sampah makanan.

2. Penyajian nasi secara prasmanan menghasilkan rata-rata jumlah sisa nasi per hari peling kecil dibandingkan cara penyajian lainnya.

3. Upaya pengurangan sampah makanan sisa konsumsi konsumen yang dapat dilakukan dari sisi warung makan antara lain menerapkan penyajian nasi secara prasmana , melakukan kampanye tentang sampah makanan dan menerapkan perbedaan porsi nasi pada warung makan.

\subsection{Saran}

1. Kebiasaan menyisakan makanan pada konsumen merupakan persoalan perilaku yang tidak mudah untuk diubah. Selain melakukan upaya pengurangan sampah makanan perlu juga dilakukan kajian tentang upaya pemanfaatan dari timbulan sampah makanan. Hal itu perlu dilakukan untuk mengurangi volume sampah di tempat pembuangan sampah dan dapat meningkatkan nilai guna dari sampah tersebut.

2. Perlu adanya kebijakan lokal mengenai cara penyajian nasi di warung makan agar upaya pengurangan sampah makanan, khususnya nasi dapat terwujud.

\section{DAFTAR PUSTAKA}

Abiad, M.G., Meho, L.I. 2018. Food loss and food waste research in The Arab world: A systematic review. Food Secur.
https://doi.org/10.1007/S12571-0180782-7.

Anriany, D., Martianto, D. 2013. Estimasi sisa nasi konsumen di beberapa jenis rumah makan di Kota Bogor. Jurnal Gizi dan Pangan.8 (1): 33-38.

Aschemann-Witzel, J., De Hooge, I., Normann, A. 2016. Consumer-Related food waste: Role of food marketing and retallers and potential for action. Sustainability7(6): 6457-6477.

Betz, A., Buchli, J., Gobel, C., Muller, C. 2014. Food waste in the Swiss food service industry-Magnitude And potential for reduction. Waste Manage. 25: 218226.

Bond, M., Meacham, T., Bhunnoo, R., Benton, T. G. 2013. Food waste within global food system. A Global Food Security Report.

[BSN] Badan Standardisasi Nasional. 1994. Metode pengambilan dan pengukuran contoh timbulan dan komposisi sampah perkotaan SNI 19-3964-1994. Jakarta (ID): BSN

Detik Food. 2014. Saat makan di restoran, harga makanan yang mahal terasa lebih enak.[imternt]. [diunduh pada 2019 Juni 23]; Tersedia pada: https://food.detik.com/info-kuliner/d2572163/saat-makan-di-restoran-hargamakanan-yang-mahal-terasa-lebih-enak.

[EIU] Economist intelligent unit. 2016. Global food security index.[internet]. [diunduh pada 2018 Mei 28]; Tersedia pada: https://foodsecurityindex.eiu.com/.

Fajri, I. 2018. Strategi peningkatan penjualan makanan tradisional sunda melalui daya tarik produk wisata kuliner di The Jayakarta Bandung Suite Hotel \& Spa. THE Journal 5 (1): 2018.

[FAO] Food and Agriculture Organization. 2009. How to feed the world in 2050. [internet]. [diunduh pada 2018 November 30]: Tersedia pada: https://www.fao.org/expert_paper/How t o_Feed the World_in_2050.pdf 
[FAO]Food and Agriculture Organization. 2011. Global Food Losses and Food Waste-Extent, Causes and Prevention. Roma(IT): FAO.

[FAO] Food and Agriculture Organization. 2014.Global initiative of food losses and waste reduction. Roma (IT): FAO.

Gustavsson, J.C., Ciderberg, U., Sonesson, R.V., Otterdijk, Meybeck, A. 2011. Global Food Losses and Food Waste. Food and Agricultural Organization. Rome (IT).

[IPCC] Intergovernmental Panel on Climate Change.2007. Impacts, Adaptation And Vulnerability. Cambridge University Press.

[KBBI] Kamus Besar Bahasa Indonesia. 2019. [internet]. [ diunduh pada 2019 Juni 27); Tersedia pada: https://kbbi.web.id/prasmanan.

Koivupuro, H., Hartikainen, H., Silvennoinen, K., Katajajuuri, J.M., Heikintalo, N., Reinikainen, A., Jalkanen, I. 2012. Influence of socio-demographical, behavioural and attitudinal factors on the amount of avoidable food waste generated in Finnish households. Int $J$ of Consumer Studies. 36 (2): 183-191.

Levis, J.W., Barlaz, M.A. 2011. What is the most environmentally beneficial way to treat commercial food waste?. Environ Sci Technol. 45: 7438-7444.

[PDDIKTI] Pangkalan Data Pendidikan Tinggi. 2018. Profil Perguruan Tinggi [Internet]. [diunduh pada 2018 oktober 18]. Tersedia pada: https://forlap.ristekdikti.go.id/perguruanti nggi/detail/ODI4RkI5NjYtMzczMy00Mz BFLTg2RkYtOTA5Qjc2NEUyNTIz

Raharjo, S., Geovani, R. 2015. Studi timbulan,komposisi, karakteristik, dan potensi daur ulang sampah non domestik Kabupaten Tanah Datar. Jurnal Teknik Lingkungan. 12(1): 27-37.

Silvennoinen, K., Heikkila, L., Katajajuuri, M., Reinikainen, A. 2015. Food waste volume and origin: case studies in The
Finnish Food Service Sector. Waste Manage. 46: 140-145.

[SIPSN] Sistem Informasi Pengelolaan Sampah Nasional. 2018. Data Pengelolaan Sampah: Komposisi Sampah [Internet]. [diunduh pada 2018 November 29]. Tersedia pada: sipsn.menlhk.go.id/?q=3a-komposissampah. 